\title{
Lactobacillus catenaformis
}

National Cancer Institute

\section{Source}

National Cancer Institute. Lactobacillus catenaformis. NCI Thesaurus. Code C86477.

A species of facultatively anaerobic, Gram positive, rod shaped bacteria in the phylum Firmicutes. This species is homofermentative and catalase negative. L. catenaformis is found in the intestinal and pulmonary cavities. 